\title{
THE GERMAN CENTER PARTY AND THE REICHSBANNER
}

\author{
A CASE STUDY IN POLITICAL AND SOCIAL \\ CONSENSUS IN THE WEIMAR REPUBLIC
}

The problem of paramilitary organizations in Germany after 1918 forms an interesting and crucial chapter in the story of the ill-fated Weimar Republic. The organizations which gained the most notoriety stood on the far political right, unreconciled and unreconcilable both to military defeat and to the republic which was the child of that defeat. But the republic did have its militant defenders, who were recruited on the democratic left and organized in the Reichsbanner. ${ }^{1}$ The history of the Reichsbanner not only vividly demonstrated "the sharpness of political antagonisms" 2 in the republic, but also reflected several developments during Germany's so-called golden years after 1924: the balance of political forces, Catholic-socialist and bourgeoissocialist relations, and in no small degree the disintegration of the Weimar Coalition (Social Democratic Party, Democratic Party, and Center Party).

It is felt that the relationship between the Reichsbanner and the Center party can be treated as one important test case of political and social stability in Germany during the 1920's. Apart from the size and relative electoral stability of the Center, and the potential contribution it could make to the Reichsbanner, this question had some far-reaching ramifications. At least three interconnected problems were brought into play, namely, unresolved social tensions inherited from pre-war Germany, the Center's attitude towards the republic, and the role of that party's republican left wing and its most outspoken representative, Joseph Wirth. Before treating these issues directly, it will be useful to

${ }^{1}$ On the history of the Reichsbanner, see the recent study by Karl Rohe, Das Reichsbanner Schwarz-Rot-Gold. Ein Beitrag zur Geschichte und Struktur der politischen Kampfverbände zur Zeit der Weimarer Republik (Düsseldorf, 1966). The present article approaches the Reichsbanner from a different perspective (since it is concerned essentially with the problems of the Center) and utilizes different sources from those used by Rohe.

2 Karl Dietrich Bracher, Die Auflösung der Weimarer Republik (3rd ed.; Villingen/Schwarzwald, 1960), p. 144. 
clarify the general character and problems of both the Center and the Reichsbanner. Most of the elements which determined the relationship between the two were already present when the Reichsbanner was organized.

The Reichsbanner was founded in February, 1924 - in the shadow of the preceeding year of crisis - by a group of Magdeburg Social Democrats led by Otto Hörsing, the irascible and unpredictable Oberpräsident of Prussian Saxony. It was conceived as a defense organization on the left, a counterweight to the right-wing paramilitary and putschist Verbände. From the outset, however, the Reichsbanner was never regarded as simply a socialist militia. To its supporters, the Reichsbanner was an organization of the frontgeneration of 1914, a mass supra-party movement to awaken new enthusiasm for the republic.

Hörsing and his associates concluded, in fact, that if the Reichsbanner became a proletarian red guard Social Democrats would become increasingly vulnerable to an anti-Marxist campaign of harassment, while the republic would be dismissed as a socialist affair, the concern of an isolated minority. It was essential, therefore, to engage the support of sympathetic elements in the Center and Democratic parties, the other two members of the Weimar Coalition. ${ }^{1}$ Although within the Social Democratic Party (SPD) the notion of including bourgeois elements in the Reichsbanner met initially with some resistance, the right wing of the party had its own way between a "red" or "black-redgold" organization. Once this decision was made, either for tactical reasons or from a more fundamental sense of political commitment, it was never reversed. ${ }^{2}$

The circumstances surrounding the Reichsbanner's founding, its tendency to reflect the internal party tensions of the SPD, and above all, its supra-party character meant that from the moment of its inception certain contradictions were built into the organization. The Reichsbanner faced a growing dilemma from 1924 to 1930 which was at once political and psychological. As the republic appeared to become more secure from the outward attacks of its enemies, the defense character of the organization ran the risk of seeming superfluous. The dilemma was circumvented by stressing the Reichsbanner's character as a militant democratic-republican popular front, and by propagandizing for a kind of emotional engagement with black-red-gold

1 Letter of Hörsing to Wilhelm Marx, Oct. 11, 1926, in Wilhelm Marx Papers 265, Köln Stadtarchiv.

2 On these problems, and on the founding of the Reichsbanner, see the discussion in Rohe, pp. 44-55. The author (p. 52) refers to the Reichsbanner as "dieses ideologisch wenig artikulierten Verbandes". 
solidarity. At the same time, in defending the republic and in marshalling popular support the Reichsbanner was forced to assume much the same external appearance and organization as its opponents on the right. It was thus exposed to attacks from the left for its "militarism" and from the right for its lack of "true national sentiment" and identification with the Weimar "system". In the midst of these problems, and in an increasingly conservative political context, the Reichsbanner was built into a mass organization and attempted to remain a rallyingpoint for the three Weimar coalition parties. Whether or not this aim could be realized remained, at best, open to question.

The larger and more stable of the two non-socialist Weimar parties, the German Center Party, had managed after 1918 to carry "the old flag into new times", 1 and therein lay the source of most of its problems. The party had grown up in the Empire as a multi-class Catholic Interessenpartei. Stigmatized by Bismarck as Reichsfeinde, leaders of the pre-war Center concentrated on cementing over class conflicts with the common interests of religion, and integrating German Catholics into the national state. Under the Bismarckian constitutional arrangement, which did not allow for party responsibility, this implied an accomodation with the status quo. But in the republic, faced with the task of making sometimes painful political decisions, and with many of its pre-war demands realized, the legendary Zentrumsturm was always in potential danger of disintegrating over the diverging social and economic interests of its members. ${ }^{2}$ How successful this incompletely politicized Volkspartei would be in overcoming these difficulties was not at all clear in the uncertain days and months after November, 1918. The difficulties did not disappear in the twenties, but on the contrary, tended to worsen.

The structural problems of the Center were complicated by other issues as well. Not the least of these was the Center's highly ambivalent attitude toward parliamentary government, a question which had not been resolved before the revolution and which remained unsettled after 1918. Similarly, as a self-styled microcosm of German political life the Center felt it could not afford to become totally a "Christianrepublican state party" as a minority of its members would have

${ }^{1}$ The title of a book by the chairman of the Baden Center, Josef Schofer, Mit der alten Fahne in die neue Zeit (Freiburg im Breisgau, 1926). On the Center in the early years of the republic see Rudolf Morsey, Die Deutsche Zentrumspartei 1917-1923 (Düsseldorf, 1966).

${ }^{2}$ Most of the recent literature on the Center makes this rather clear. See in particular the excellent brief survey of Josef Becker, "Die Deutsche Zentrumspartei 1918-1933. Grundprobleme ihrer Entwicklung", in: Aus Politik und Zeitgeschichte. Beilage zur Wochenzeitung Das Parlament (Mar. 13, 1968), pp. 3-15. 
wanted. ${ }^{1}$ Instead, party leaders insisted that the Center was a "constitutional party". This formula could indeed by justified with reference to the Center's past tradition, but it left unanswered the more basic question of the exact degree of the party's commitment to the republic. ${ }^{2}$ The Center performed yeoman service for the republic in its early years, and showed considerable political responsibility as well as not a little nationalism. But a final answer to this question was not forthcoming until 1933. The question became all the more important as the republic entered its few relatively stable years. Quite clearly, the Center was in the republic but not of it.

On an equally crucial matter, the Center's cooperation with the SPD after 1918 had never been more than a tactical adjustment, and an uncomfortable one at that. The Center had worked with the socialists, in the words of Carl Bachem, the party's historian, "simply because it was forced to do so by circumstances". ${ }^{3}$ The Center's watchword in the 1920's was the Volksgemeinschaft, a term later expropriated by the National Socialists but which meant to the Center's leaders a coalition of forces from the Nationalists (DNVP) on the right to the SPD on the left. However one chose to define this concept, and whatever traditional, moral, or non-rational attraction it might have exercised, its very imprecision was its biggest asset. The Volksgemeinschaft was designed to preserve the Center's tactical flexibility as a pivotal party of the middle, as well as its implicit freedom to work with the political right. And to the degree that it rejected the concept of class struggle, particularly in the hands of some Catholic labor leaders and trade unionists, the Volksgemeinschaft was anti-socialist. ${ }^{4}$ The Center's role in the Reichsbanner thus bore

1 Joseph Wirth, "Die Erfurter Tagung des Zentrums", in: Frankfurter Zeitung, No 831, Nov. 7, 1926; "Die deutsche Republik und die Zentrumspartei", in: Deutsche Republik, I, Heft 3 (1926-27), pp. 3-4 (hereafter cited as DR).

${ }^{2}$ Letter of Wilhelm Marx to Carl Bachem, Jan. 11, 1928 in Carl Bachem Papers 923, Köln Stadtarchiv. Cf. Offizieller Bericht des Vierten Reichsparteitages der Deutschen Zentrumspartei. Tagung zu Cassel am 16. und 17. November 1925 (Berlin, n.d. [1925]), p. 112 (hereafter cited as Off. Ber. 1925). It can also be argued that the Center historically embodied both a "democratic" southwest German tradition and a "constitutional" Rhenish-Prussian tradition, and that the "constitutional party" formula represented a victory of the latter over the former. See Karl Buchheim, "Das Zentrum und die Republik", in: Hochland, LIX (Dec., 1966), pp. 111-28.

${ }^{3}$ Undated ms. "Warum das Zentrum mit dem Soz. Dem. zusammengegangen ist", Bachem Papers 923. The same argument was used by Bachem in his Vorgeschichte, Geschichte und Politik des Deutschen Zentrumspartei (9 vols; Köln, 1927-32), VIII, pp. 274-77.

${ }^{4}$ See Morsey, pp. 555, 577-78, 614. Morsey also points out (p. 610) that as early as 1919 the Center's relations with the SPD had "noticeably cooled". The Volksgemeinschaft idea was widely championed in Catholic workers' circles, although 
directly on the critical issue of its relationship with the SPD. This issue was the source of many of the internecine battles which plagued the party throughout the mid-twenties. A key figure in these intraparty struggles and in the Center-Reichsbanner problem was the controversial ex-Chancellor, Joseph Wirth.

Wirth was generally regarded as the heir to Matthias Erzberger in the Center's left wing, but perhaps even more than Erzberger he became the enfant terrible of the Center and the despair of party elders. ${ }^{1}$ His wholehearted commitment to and identification with the republic was never marked by the equivocation of most of the Center's leaders. Wirth's republicanism was due in part to his own Baden political tradition and milieu, in part to an almost emotional concept of a "social democracy", and in large part also to the fact that without the revolution of 1918 his political star never would have ascended so rapidly. As Chancellor in 1921-22, Wirth's "policy of fulfillment" abroad and left-of-center political course at home enjoyed little success. But they led him to make a memorable Reichstag speech after Walther Rathenau's assassination in June, 1922, in which he concluded, pointing dramatically to the Nationalist delegation: "This enemy stands on the right!" 2 Wirth's castigation of the political right was never forgiven or forgotten. Nationalist leaders went so far as to maintain in succeeding years that he was the greatest single obstacle to Center-Nationalist cooperation. ${ }^{3}$ Wirth was backed by his own

labor spokesmen were careful to emphasize that it could not be realized through a reactionary rightwing government, or "Bürgerblock". See Westdeutsche Arbeiterzeitung, No 37, Sept. 13, 1924 (hereafter cited as WAZ).

1 "Things go with Wirth in large assemblies", wrote Carl Bachem pessimistically, "just as they used to with Erzberger, only much worse ... I do not think it is possible to control Wirth's madness, and thereby he will destroy the party." Letter to Gustav Trunk, Dec. 17, 1925, Bachem Papers 828. Too close a comparison between Wirth and Erzberger can be misleading, however. Both men played the role of Aussenseiter in the Center, but they were not close associates and had Erzberger lived after 1921 it is not at all certain he would have supported Wirth. The author is presently completing a political biography of Wirth. a Verhandlungen des Reichstags, Vol. 356 (June 25, 1922), p. 8058. Morsey's assertion (op. cit., pp. 491-92) that Wirth's speech "imprisoned" him may be basically correct, but needs further explanation and some modification. Cf. Wirth's remarks during his exile in the 1930's: Josef Wirth, "Die deutsche Neutralitätspolitik der Jahre 1922-1932. Erstveröffentlichung einer in Luzern im Jahre 1936 gehaltenen Rede", in: Blätter für deutsche und internationale Politik, $\mathrm{V}(1960)$, p. 1017 ; undated report [Nov., 1937] of a meeting between Wirth and Alsatian politicians, in Auswärtiges Amt: Abt. Inland II geheim (National Archives Microcopy T-120), serial 2378, roll 1317, frame D497549.

${ }^{3}$ Cf. debates over continuation of the Republikschutzgesetz in 1925 , Verhandlungen des Reichstags, Vol. 385 (Mar. 18, 1925), pp. 1146-50; Lewis Hertzman, 
party in 1922, although without much enthusiasm; he clearly stood for a position which was in a minority.

Wirth's "committed republicanism" together with his extraordinary rhetorical talents and his "contact with the masses" - mainstays of his rapid rise in politics after the war - caused increasing concern among party leaders after 1922. The former Chancellor was temperamental and outspoken, traits which led him into more than one ill-considered tactical blunder. ${ }^{1}$ Furthermore, he was left with neither influence in the party nor a position of responsibility in the governments in which the Center participated from 1923 to 1929 . The situation was not offset by the prestige of his former role as Chancellor. After considerable initial hesitation in joining the Reichsbanner - giving as his reasons "internal party difficulties" - Wirth turned increasingly to the organization to criticize the rightward drift of his party. ${ }^{2}$ His public activity in the Reichsbanner over the next three years was perhaps the most typical aspect of his political career in the mid-twenties. ${ }^{3}$

It was not accidental that support for Wirth generally related to support given to the Reichsbanner as well. The two principal weaknesses of the Wirth circle, however, were its size and its heterogeneity. The Center youth organization, the Windthorstbund; the "Frankfurt circle" of young intellectuals and publicists; the Catholic Workers' Associations, whose chief spokesman was the labor editor Joseph Joos; 4 part of Wirth's own Baden Center; the important and politically leftist Berlin Center Diaspora - these and other groups loosely constituted what might be called the republican left in the Center. They could be enthusiastic, even effusive, champions of the Reichsbanner

DNVP. Right-Wing Opposition in the Weimar Republic (Lincoln, Neb., 1963) p. 233.

1 Joseph Joos, "Dr. Wirth und die Reichstagfraktion", in: WAZ, No 38, Sept. 19, 1925; Joseph Becker, "Joseph Wirth und die Krise des Zentrums während des IV. Kabinettes Marx (1927-1928)", in: Zeitschrift für die Geschichte des Oberrheins, CIX (1961), pp. 403-404, 469-71. See also the portrait by Heinrich Köhler, Lebenserinnerungen des Politikers und Staatsmannes 1878-1949, ed. by Josef Becker (Stuttgart, 1964), pp. 169-88. Köhler, one of Wirth's erstwhile Centrist colleagues from Baden and later (1927-28) Reich finance minister, recognized Wirth's political talents but bitterly condemned him as a demagogue and "the greatest egoist in the post-war Center".

"Letter of Wirth to Hörsing, July 30, 1924, cited in Rohe, p. 280.

${ }^{3}$ Morsey refers to Wirth's "Extratouren". See "Das Zentrum zwischen den Fronten", in: Der Weg in die Diktatur 1918-1933 (Munich, 1962), p. 99.

4 The Katholische Arbeitervereine were not trade unions, but rather cultural organizations under episcopal jurisdiction. Joos was a personal friend of Wirth and generally acted in his behalf as a go-between with party leaders. But Wirth received more consistent support from local Catholic labor leaders. 
and "their" Wirth. ${ }^{1}$ But their influence in the upper echelons of the party was negligible.

Moreover, the notion of a "left wing" in the Center, while basically correct, must nevertheless be used with some care. Catholic Workers' Associations usually (although not in every case) supported Wirth, but the larger and more powerful interconfessional Christian Trade Unions did not, just as they had not supported Erzberger during the war. The CTU's chairman, Adam Stegerwald, was openly hostile to the Reichsbanner and was highly skeptical of the fitness of socialists to help govern Germany. Stegerwald preferred instead a political course involving cooperation with the Nationalists and was diametrically opposed to Wirth and to the pro-Reichsbanner elements in the Center. ${ }^{2}$

In addition, a certain ideological clarity was lacking among some of Wirth's followers, particularly in the youth groups. Their political ideas in any case had little to do with traditional political catagories of "right" and "left". One of the principal concerns of these groups was political leadership and the republic's leaders seemed to be stuck in the past. ${ }^{3}$ Even Windthorstbund members who later vigorously supported the Reichsbanner maintained in 1923 that the republic of Weimar was not really the ideal of republican youth. They were striving for the republic not as it was, but rather as it ought to become. ${ }^{4}$ In 1926, Joos

${ }^{1}$ Letter of Adolf Kalesse to Marx, June 1, 1927, Marx Papers 239. Cf. also WAZ, No 47, Nov. 22, 1924; Willi Drees, "Wir glauben an unsere Zukunft", in: Allgemeine Rundschau, XXIII (July 3, 1926), pp. 466-67; Das Junge Zentrum, IV (June/July, 1927), p. 35, and ibid. (Aug., 1927), pp. 153-54.

2 At the Center's party congress in 1925, Wirth and Stegerwald clashed head-on over the issue of political direction for the party and Center participation in the Reichsbanner. Cf. Off. Ber. 1925, pp. 30-38, 70-78. Stegerwald's penchant for a right-wing political course was tactical as much as anything else. The nonsocialist federation of trade unions, which included the Christian Trade Unions, the Deutscher Gewerkschaftsbund (founded in 1919 as a counterpoise to the socialist Allgemeiner Deutscher Gewerkschaftsbund), included important contingents from the Nationalist party. As chairman of the DGB, Stegerwald was constantly preoccupied with problems of organizational unity. On the Christian Trade Unions and the Reichsbanner see "Reichsbanner und christliche Gewerkschaften", in : Zentralblatt der christlichen Gewerkschaften, XXV (1925), p. 98; "Reichsbanner und Zentrum", in: Kölnische Volkszeitung, No 546, July 27, 1927; remarks of Stegerwald in Verhandlungen des Reichstags, Vol. 393 (Mar. 29, 1928), p. 13893; letter of Marx to Dr Stenzel, May 13, 1930, Marx Papers 265.

${ }^{3}$ Joseph Joos, Die politische Ideenwelt des Zentrums (Karlsruhe, 1928), pp. 32-39; Walter Dirks in Rhein-Mainische Volkszeitung, No 183, Aug. 9, 1926; Heinrich Krone, "Am Ende?", in: Das Junge Zentrum, IV (Jan., 1927), pp. 1-3; Werner Becker, "Die Politik der jungen Generation in Europa", in: Abendland, I (Aug., 1926), pp. 328-30.

${ }^{4}$ Germania, No 307, Nov. 5, 1923. 
could write of the need for "volkhafte Führer". In the same year Heinrich Brüning, who had quite a different set of prerequisites for political leadership from those of Wirth, found an outlet for his ideas of a conservative democracy in the journal of the Windthorstbund. ${ }^{1}$ Engagement with the Reichsbanner in the mid-twenties and support for Wirth provided one answer to the leadership problem, both in the Center and in the republic. But as events after 1930 proved, the support could just as suddenly shift to other quarters.

The enthusiastic if unclear support of Wirth's followers was one thing. The attitude of the Center's leaders was something else, and these leaders had no real interest either in the Reichsbanner or for a renewed opening to the left. Wirth did not hesitate to criticize his party's obvious reluctance to provide more than lip service to the Reichsbanner idea. ${ }^{2}$ But the left-wing forces in the Center were too fragmented to affect more than temporarily the basic orientation of the party. Although he later asserted that he had been an energetic supporter of the Reichsbanner from the outset, party chairman and Chancellor Wilhelm Marx ignored invitations to become a member and did not actually join until May, $1925 .^{3}$ The presidential elections of that year, with Marx as the run-off Volksblock candidate of the democratic left, seemed for a time to indicate a return to Center-SPD cooperation at the national level. Despite public expressions of goodwill from Marx, however, and despite attempts to keep the Volksblock a going political concern after the elections, cooperation with the left was barely more than an illusion. Marx had been under considerable pressure since late 1924 to move towards at least temporary cooperation with the political right. The connection with the SPD in the presidential elections had not eased this pressure. ${ }^{4}$

Center-Nationalist cooperation on agrarian tax and tariff policies in the summer of 1925 finally led Wirth to take the dramatic if futile

I Joos to Julius Stocky, Jan. 8, 1926, Marx Papers 238; Heinrich Brüning, "Führer und Gefolgschaft in der modernen Demokratie", in: Das Junge Zentrum, III (Aug., 1926), pp. 180-84. Cf. Brüning's comments twenty years later on Center-socialist cooperation, and the possibility of forming a united "labor party" out of members of the Center and the SPD: Brüning to Wilhelm Sollmann, Aug. 20, 1946, in Wilhelm Sollmann Papers (Swarthmore College Peace Collection, Swarthmore, Pa.), DG 45, Box 1.

2 Off. Ber. 1925, p. 78; Wirth, "Wir bleiben!', in: Das Reichsbanner, IV (Sept. $1,1927)$.

3 Ms. "Reichsbanner", Marx Papers 265; Rohe, p. 291.

4 Cf. John K. Zeender, "The German Catholics and the Presidential Election of 1925", in: Journal of Modern History, XXXV (Dec., 1963), pp. 366-84. See also Karl Holl, "Konfessionalität, Konfessionalismus und demokratische Republik Zu einigen Aspekten der Reichspräsidentenwahl von 1925", in: Vierteljahrshefte für Zeitgeschichte, XVII (July, 1969), pp. 254-75. 
step of walking out of the Center's Reichstag Fraktion. The gesture was supported by his followers in the Center, applauded by the Reichsbanner, and precipitated the first of several serious crises for the party. But it was perhaps more an indication of the political impotence of the Wirth circle than anything else, and did not in any case alter the basic political situation. ${ }^{1}$ Yet Wirth's actions could and did stir up public controversy, the very thing the Center's leaders hoped to avoid. The enthusiastic Reichsbanner assemblies which invariably accompanied Wirth's speaking forays were not regarded as the proper place to wash the Center's dirty linen. ${ }^{2}$

Marx and other party leaders, in fact, had several reasons for finding Center membership in the Reichsbanner awkward by the fall of 1925. In the course of the presidential elections of that year, the Center had become financially indebted to the Reichsbanner. Efforts to collect the money from right-wing industrialist circles in the party were undoubtedly compromised by protests from these same circles over Wirth's activities. He was stirring up the workers in the RhineRuhr area, Catholic rightists charged, and his constant appearances with socialists before Reichsbanner assemblies would come to no good. ${ }^{3}$ Some agrarians and industrialists even threatened a walkout unless the Center expelled Wirth and loosened remaining connections with the SPD, including participation in the Reichsbanner. ${ }^{4}$ The Center's chairman must have been particularly aware of the sensitivity of this issue. Class tensions in the Ruhr ran high, and Marx himself was

1 Report of Hermann Pünder, Sept. 9, 1925, in Alte Reichskanzlei: Partei 4, Zentrumspartei 1919-1926 (National Archives Microcopy T-120), serial L1833, reel 5713, frames L530127-9; Ms. "Der Austritt Dr. Wirths aus der Fraktion im Jahre 1925", Marx Papers 236. Cf. Georg Decker, "Die Zentrumskrise", in: Die Gesellschaft, II, 2 (1925), pp. 410-28.

${ }^{2}$ Munich police report, March 1, 1926 on Wirth's appearance before a capacity Reichsbanner rally, in NSDAP Hauptarchiv (Hoover Institution Microfilm Copy), reel 93, folder 1902; Marx to the secretary of the Düsseldorf Catholic Workers' Association, Drösser, Dec. 10, 1925, Marx Papers 237.

${ }^{3}$ Letters to Marx from Heinrich Vockel, Sept. 18, 1925 and Geheimrat Bürger, Dec. 16, 1925, Marx Papers 237. Rudolf ten Hompel to Marx, Jan. 14, 1926, ibid. 238. Carl Bachem complained that Wirth should not be allowed to address Center assemblies, particularly working-class audiences, "solange er in Versammlungen des 'Banner schwarz-rot-gold' auftrete und dort Stimmung gegen die Zentrumsfraktion mache... [M]it den Arbeitern und den so wenig verstandsfähigen grossstädtischen Massen allein können wirs nicht machen." Bachem to Gustav Trunk, Dec. 17, 1925, Bachem Papers 828.

" "Have you forgotten", one rightist complained to Marx, "who was the chief power in the Center in the years 1870-90? And which class in the future it must be again?" - a clear reference to the Catholic upper middle class and aristocratic Honoratioren in the pre-war Center. Th. Hebring to Marx, Nov. 2, 1926, Marx Papers 238. 
already suspect in some Catholic working-class circles after his cabinet extensively subsidized heavy industry in the west in late $1924 .{ }^{1}$

Center membership in the Reichsbanner was also regarded by many as an obstacle to reunification with the Bavarian People's Party (BVP), which had seceeded from the parent Center in 1920. There were several reasons for this. Most Bavarian Catholics disliked the "Prussian" Hörsing, were offended by the Reichsbanner's strong stand for the unitary state, and not least of all, refused to associate with Social Democrats in a militant republican (and anti-monarchist) organization. Furthermore, close ties existed between the Reichsbanner and the Austrian Social Democratic Republikanischer Schutzbund. Unlike the Reichsbanner, the Schutzbund was both in theory and practice a strictly socialist organization. Wirth's frequent appearances before joint Reichsbanner-Schutzbund rallies in Austria only increased his unpopularity in Bavarian and Austrian Catholic circles, and further complicated the sensitive relationship between the Center, BVP, and Austrian Christian-Social party. ${ }^{2}$

Influential Austrians and south Germans also attempted to obtain a withdrawal of the Center from the Reichsbanner, or barring that, at least a withdrawal of Marx as the Center's most prominent personality. Center participation in the Reichsbanner, it was claimed, and the "toleration" of Reichsbanner-Schutzbund mass demonstrations such as one which took place in Vienna in July, 1926, jeopardized "Catholic unity", Austro-German relations, and a possible future Anschluss. ${ }^{3}$ Marx defended the Center's role in the Reichsbanner, and he obtained assurances from Hörsing in the fall of 1926 that incidents such as the one in July would be avoided in the future. But a pronounced cooling of relations between the leadership of the Center and the Reichsbanner had set in, and the Center's chairman concluded that Hörsing was untrustworthy. ${ }^{4}$

1 Marx dated the beginning of his later troubles with Catholic trade unionists from the events of late 1924. See Ms. "Meinungsverschiedenheiten mit den christlichen Arbeitern", Marx Papers 241.

2 Otto Kunze, "Christliche Politik", in: Allgemeine Rundschau, XXI (Oct. 23, 1924), pp. 681-82; Bayerischer Kurier, No 219, Aug. 9, 1926 and No 253, Sept. 10, 1927; "Bayerische Briefe", in: Das Junge Zentrum, IV (Jan., 1927), pp. 4-10; Friedrich Funder, Als Österreich den Sturm bestand (Vienna, 1957), pp. 119-20.

${ }^{3}$ Nationalrat Heinrich Mataja to Marx, July 22, 1926 and Aug. 17, 1926; F. Krauss to Marx, Oct. 6, 1926; Hugo Graf von Lerchenfeld to Marx, Oct. 23, 1926, all in Marx Papers 265. Cf. Julius Deutsch (chairman of the Schutzbund) to Hörsing, Oct. 18, 1926, copy in ibid.

4 Marx to Mataja, Aug. 3 and Sept. 14, 1926, and Hörsing to Marx, Oct. 11, 1926, Marx Papers 265. Marx was not the only one to have serious reservations about participation in the Reichsbanner in 1926; the middle-class leaders of the 
Finally, the most profound difficulty in the Center's relations with the Reichsbanner, and the one which aroused the most public controversy, was an ideological one. Reasons of Weltanschaunng had of course long been a stumbling block between Catholics and socialists, reasons which were not abandoned in the tenuous cooperation between the Center and the SPD. Many German Catholic leaders feared that too close an association with socialists and participation in the Reichsbanner, a "socialist fighting organization", would destroy or at least dilute religious fervor. The Catholic hierarchy reacted accordingly, and discouraged or in some cases prohibited Catholic participation in the Reichsbanner. ${ }^{1}$

Clerical prohibition, however, was in itself no longer sufficient to keep Catholics out of the Reichsbanner or away from socialist contamination. The joint Communist-socialist referendum in the spring of 1926 to expropriate the properties of former ruling houses of Imperial Germany quite clearly demonstrated this. The Reichsbanner came out in full strength in favor of the referendum, but the Center's executive committee and Fraktion leadership in Berlin, as well as the German bishops, demanded that Catholic voters remain at home. As anticipated, the referendum failed to pass, but those voting for it numbered more than three million over the combined socialist and Communist vote in the December, 1924 Reichstag elections. Many of these votes came from Center constituencies, and local groups of the Windthorstbund in Berlin and elsewhere openly defied the ban placed on the referendum. ${ }^{2}$ The ensuing uproar touched off renewed demands that the Center dissociate itself from the Reichsbanner, lasting several months. ${ }^{3}$

Wirth's conduct in the princely properties controversy was, to say the least, ambiguous. The former Chancellor was most conspicuous, in fact, by his silence on the whole question. Wirth based his position on the settlement of 1918 between the princes and the Baden govern-

DDP felt the same way. The chairman of that party, Erich Koch-Weser, concluded: "Wir hatten gehofft dass wir durch das Reichsbanner weitere Kreise der Sozialdemokraten zu uns herüberziehen würden. Ich halte diese Hoffnung für verfehlt; denn ich sehe immer wieder, wie die radikalen Elemente sich bei diesen gemeinsamen Organisation durchsetzen." Meeting of the DDP Ausschuss, Nov. 28, 1926, copy in NSDAP-HA, 37/731.

1 Archbishop cardinal Bertram of Breslau to Marx, Nov. 24, 1925, and Heinrich Vockel to Marx, Sept. 14, 1926, Marx Papers 265; "Zurück aus dem Sumpf! Hinein in den Turm!", in: Allgemeine Rundschau, XXIII (June 26, 1926), p. 402; remarks of Prälat Linneborn in Off. Ber. 1925, p. 106.

2 Das Junge Zentrum, III (July, 1926), pp. 137-38.

3 Otto Kunze, "Quo Vadis, katholische Jugend?", in: Allgemeine Rundschau, XXIII (June 19, 1926), p. 386; materials in NSDAP-HA, 94/1906, folder marked "Reichsbanner und Zentrum". 
ment (of which he had been a member). Apparently unwilling to come out in favor of expropriation without indemnification, he also was probably unwilling to alienate his supporters - a stand remarkably like that of the SPD, which had been maneuvered into the referendum issue by the actions of the Communists. Acting from mixed motives, therefore, Wirth concluded under the circumstances that silence was the best policy. The net effect of that silence was almost the same as approval of the proposed referendum and was interpreted in that fashion by Wirth's young followers. Party leaders could only deplore the results. ${ }^{1}$

Religious considerations often were blurred by rather thinly disguised class instincts. But they were among the most commonly used arguments by arch-conservative Catholics in and out of the Center, who bitterly fought against continued cooperation between the Center and the SPD. Those such as Wirth who took an advanced stand in supporting the Reichsbanner came under increasingly heavy criticism and abuse. Wirth was a "Blutwurst" charged one Catholic rightist - "black on the outside, red on the inside". In a similar vein, Carl Bachem charged that Wirth simply used his religion "to justify Communist tendencies". ${ }^{2}$ Wirth, however, made no attempt to hide his belief that "cultural policy" (specifically, confessional schools) was a weak substitute for a political coalition. Worse still, it had become a transparent device for tying the Center to the right. It was absurd, Wirth insisted, to cry religion was in danger. It was not religion which the Reichsbanner threatened; "the only thing in danger is reaction". 3 Statements such as these invariably drew enormous rounds of applause from Wirth's Reichsbanner audiences. The Center's elders were somewhat less than enthusiastic, and wondered where his rhetorical flamboyance would end.

To party leaders, the alarming juxtaposition between the Center's role in the Reichsbanner and the casual attitude of the Wirth circle towards the party's confessional objectives was well illustrated by Wirth's refusal to cancel an excursion before the Thuringian Reichsbanner in late 1926. Both Marx and local party leaders insisted that the Center's alliance with right-wing political forces in the Landtag had "put through many important demands of Thuringian Catholics";

1 Ms. "Dr. Wirth und die Republikanische Union", Marx Papers 236.

2 Cf. Otto Rako, Katholizismus und Zentrumspolitik zu Sozialismus und Reichsbanner (Berlin, 1930), p. 29; Carl Bachem to Felix Porsch, Dec. 16, 1925, Bachem Papers 828.

${ }^{3}$ Off. Ber. 1925, pp. 30-38; Frankfurter Zeitung, No 397, May 31, 1927 and No 414, June 7, 1927. 
there had been "no other way". Political extremism on the right and on the left ran strong in Thuringia, and with Landtag elections scheduled for early 1927 Wirth could do irreparable damage to this delicate situation. But party leaders were unsuccessful in preventing his appearance with the Reichsbanner. ${ }^{1}$

The formation of Marx's right-wing cabinet in January, 1927, brought Center-Reichsbanner relations to the point of no return. The tensions within the Center occasioned by this coalition were apparent from the very beginning. ${ }^{2}$ Marx found himself, Janus-like but unwittingly, caught between his membership in the Reichsbanner and his willingness to cooperate with a part of the "national opposition". As the Chancellor found out, there was unfortunately no remaining middle ground by 1927 - if, indeed, there had ever been one. The Reichsbanner was not the only question that the Center faced in 1927. But it was a question which one way or another touched on all other problems; the political dilemma caused by the party's role in the Reichsbanner was never more painfully apparent.

Hörsing, on the other hand, was in the awkward position of having to defend Marx and Heinrich Köhler, the two Reichsbanner Centrists in the cabinet, ${ }^{3}$ while at the same time condemning the "reactionary Bürgerblock". Wirth also lost no time in the attack on Marx's cabinet before Reichsbanner gatherings, and called for the government's downfall. The attacks at once involved him in a breach of party discipline for which he was condemned by party authorities. ${ }^{4}$ Matters were finally brought to a head by riots which broke out in Vienna on July 15-16, 1927, involving some members of the Austrian Schutzbund. Although the situation was far from clear, Hörsing dispatched a message of sympathy to the Schutzbund which not only proclaimed solidarity between the Reichsbanner and the Austrian organization, but which also condemned the actions of the Austrian government in the affair. ${ }^{5}$ Marx responded by resigning from the Reichsbanner.

Hörsing's behavior may indeed have forced Marx's hand, as the Chancellor later insisted. ${ }^{6}$ But for a normally circumspect politician,

1 See the exchange of letters relating to this incident in Marx Papers 238: $\mathbf{H}$. Rademacher [secretary of the Thuringian Center] to Wirth, Nov. 18, 1926; Wirth to Rademacher, Nov. 23, 1926; Dr Schomberg to Wirth, Nov. 29, 1926; Rademacher to Marx, Dec. 28, 1926.

2 On the Center's crisis in 1927 see Becker, "Wirth und die Krise des Zentrums", passim.

${ }^{3}$ DR, I, Heft 16 (1926-27), p. 8.

${ }^{4}$ Cf. the issues of DR, I (1926-27): Heft 26, pp. 98-103; Heft 30, pp. 225-29;

Heft 32, pp. 289-93. Letter of Marx to Wirth, May 20, 1927, Marx Papers 239.

5 Vorwärts, No 172, July 19, 1927.

-Ms. "Reichsbanner", Marx Papers 265. 
Marx's own conduct in the Reichsbanner crisis of 1927 betrayed an almost incredible short-sightedness. Perhaps counting on more support from his own party than he actually received, ${ }^{1}$ Marx either badly underestimated the effect his action would have on Catholic militant republicans, or else he knew and did not care. One hostile voice declared: "We remain what we have been, loyal members of the Reichsbanner, with or without Marx and if necessary against him". ${ }^{2}$ Wirth also did nothing to mend his already tattered relations with his own party when he took a public stand in the affair on the side of Hörsing. ${ }^{3}$

Marx's action was never duplicated by other prominent party leaders, and no mass exit from the Reichsbanner occurred. With Reichstag elections due in a few months, and on the eve of a fight with the Wirth group over confessional schools, the Center's tacticians were not prepared to exacerbate already dangerous intra-party battles. Instead, the party concentrated upon "guarantees" to secure the Reichsbanner's non-party character, although Joseph Joos proposed dividing the organization into three "columns" corresponding to the major party divisions. The plan would have meant a tacit abandonment of a supra-party republican front, and for that reason was not seriously considered. ${ }^{4}$

The Marx-Hörsing controversy of 1927 had its counterpart in the climax of Wirth's struggle with his own party. That struggle shattered long-standing friendships, contributed to a nervous breakdown suffered by Marx early in 1928, and ended in the removal of Wirth's name from the Baden Center party list before the Reichstag elections of that year. Moreover, the controversies surrounding the Marx government and its collapse left a residue of bitterness which poisoned the atmosphere of Hermann Müller's "Great Coalition" cabinet of 1928-30.

The Wirth case in the Center shared certain aspects in common with Hörsing's problems in the SPD. Both Wirth and Hörsing were Schreckenskinder to their respective parties. Marx's action in 1927 was not, after all, entirely unprovoked; the controversy centered on the Chancellor's over-response. Hörsing's proclamation to the Schutzbund was simply the latest and most serious indiscretion in a long series of similar rash actions. Even though a compromise between the Center

${ }^{1}$ Heinrich Vockel to Marx, July 23, 25 and 29, 1927, Marx Papers 265.

2 "Bekenntnis zum Reichsbanner", in: Vorwärts, No 185, Aug. 3, 1927. Cf. Münchener Post, July 27, 1927; Werner Thormann, "Zentrum und Reichsbanner", in: Rhein-Mainische Volkszeitung, No 169, July 26, 1927.

3 DR, I, Heft 41 (1926-27), pp. 581-83; Berliner Tageblatt, No 358, July 31, 1927.

4 "Rundschreiben", signed by Heinrich Krone (Aug. 20, 1927), Marx Papers 265; Vockel to Marx, July 29, 1927, ibid.; Kölnische Volkszeitung, No 552, July 29, 1927. 
and the Reichsbanner's leaders was worked out in 1927, many Centrists felt at the time that Hörsing would "still break a great deal of china". Several of Hörsing's fellow Social Democrats (among them, Carl Severing), had been critical of the Reichsbanner's Bundesfïhrer for years, and were fearful of where he would turn next. The solution to Hörsing's problems involved his leaving both the SPD and the Reichsbanner in 1932, and establishing his own party. ${ }^{1}$ Wirth, however, concluded shortly after the 1928 elections that leaving the Center was out of the question. ${ }^{2} \mathrm{He}$ may have been a rebel and an outsider; he was not a schismatic.

The growing distance of the Center from the Reichsbanner was clearly demonstrated with the formation of the Brüning cabinet in 1930 - mistakenly tagged by the Reichsbanner as simply another version of the Bürgerblock. Not only did increased friction result from Reichsbanner demonstrations against the new government, but the Center also did everything it could to discourage or prevent its members from playing an active role in the organization. ${ }^{3}$ Once again the Center avoided a definite break with the Reichsbanner, for reasons previously discussed as well as because the Brüning political constellation required at least toleration by the left. ${ }^{4}$ While the Center's connection with the Reichsbanner was thus never entirely lost, it ceased after 1930 to have any relevance to political forces in Germany.

What conclusions can be drawn concerning the Center's role in the Reichsbanner? So far as Wirth was concerned, support for the Reichsbanner meant keeping bridges built to the SPD and to the large part of the working masses, "Germany's poorest sons", 5 whom that party

1 Report of a meeting of Center leaders in the Reichsbanner, July 29, 1927 in Marx Papers 265; Carl Severing, Mein Lebensweg (Köln, 1950), II, pp. 93-94; Rohe, pp. 379-81.

2 "Abschied vom Zentrum?", in: DR, II (July 6, 1928), pp. 1273-78.

${ }^{3}$ Germania, No 173, April 12, 1930; Nikolaus Gross, "Unser Weg", in: WAZ, No 19, May 10, 1930; police report, "Reichsbanner Schwarz-Rot-Gold, Gau Württemberg" (April 24, 1930), pp. 4-7, copy in NSDAP-HA, 58/1403; Marx to Dr Stenzel, May 13, 1930, Marx Papers 265.

4 Leading to complaints, not entirely without foundation, that the Center simply "used" the Reichsbanner. While the left wing of the SPD hotly criticized Hörsing's renewed call for "Überparteilichkeit" in the Reichsbanner after the formation of the Brüning government, Center supporters of the Reichsbanner praised that same position. Cf. Kurt Laumann, "Zentrum, Sozialdemokratie, und Reichsbanner", in: Der Klassenkampf, IV, No 12 (1930), 359-64; DR, IV (April 19, 1930), p. 868.

${ }^{5}$ Wirth, "Die Republikaner und ihr Staat", in: DR, I, Heft 12 (1926-27), pp. 1-3. Cf. Wirth's similar statements on the Center workers in 1933: Josef Becker, "Zentrum und Ermächtigungsgesetz 1933", in: Vierteljahrshefte für Zeitgeschichte, IX (April, 1961), pp. 208-210. 
represented. The Reichsbanner was always far more to him than simply a defense organization. It was a means to integrate the working class into the republic, and when the massed black-red-gold banners went through the streets, he wrote, "thousands upon thousands, whether they wanted to or not, observed the movement for the new state". ${ }^{1}$ Workers must not be forced to reject the republic, and socialists must never again be forced back to their pre-war position of isolation. One of the most crucial issues, Wirth insisted, was between the concepts of ideology and Staatspartei within the SPD itself. ${ }^{2}$ Wirth's vision of a republican, politicized, and "de-confessionalized" Center found its counterpart in his idea of a "de-ideologized" SPD, an idea shared by Social Democratic moderates as well. ${ }^{3}$

Wirth's republican activism was further underscored by his rather ill-prepared and improvised launching of a Republikanische Union in July, 1926. The move was made with at least the nominal cooperation of Reichstag president Paul Löbe of the SPD and the Baden Democrat Ludwig Haas. Wirth's intention was to create a broad republican front for the leaders of the three Weimar coalition parties which would serve, in a sense, to complement the Reichsbanner. It is rather unlikely, however, that the former Chancellor actually was prepared to fuse left-wing democratic forces and moderate socialists into an organization to replace the parties, or some of them. He did, on occasion, warn that the parties "must rise above themselves if they do not want to be dissolved as bearers of the political will one day by the Verbände". ${ }^{4}$ In the long run, however, the Reichsbanner never displayed more than a passing interest in such ideas. And widespread speculation to the contrary, Wirth himself was not really inclined to found new parties or amalgamations of parties. He never bothered to develop any concrete plans, and his Republican Union was not aimed in this direction. The plans belonged mainly to some of Wirth's supporters, who had

1 Wirth, "Sozialisten, Katholiken, und der deutsche Staat", in: DR, III (Jan. 25, 1929), pp. 515-16; Verhandlungen des Reichstags, Vol. 393 (Mar. 29, 1928), pp. 1315-19.

2 Wirth, "Um das neue Kabinett", in: DR, I, Heft 9 (1926-27), pp. 17-21. Cf. Wirth's statement: "Die [im Reichsbanner] vertretenen Parteien versuche ich zum Staat zu führen, damit sie die politischen Aufgaben des Tages staatspolitisch sehen lernen. Damit wird selbstverständlich im Politischen der Klassenkampfgedanke überwunden." Letter ("Promemoria") of Wirth to Prälat Dr Schofer, Sept. 11, 1927, copy in Marx Papers 240 (also printed in Becker, "Wirth und die Krise des Zentrums", pp. 450-61).

"Wilhelm Sollmann, "Arbeitermassen und Staatspolitik", in: DR, I, Heft 2 (1926-27), pp. 15-18; Sollmann, "Nation und Sozialismus", in: Das Reichsbanner, IV (Feb. 19, 1927); undated Ms. "Die Staatsidee der Sozialdemokratie", Sollmann Papers, Box 15.

"Wirth, "Wir bleiben!", in: Das Reichsbanner, IV (Sept. 1, 1927). 
concluded that a complete realignment of Germany's party structure was in order, and who were reckoning with the dissolution of the Center. ${ }^{1}$

It would be perhaps too easy to dismiss Wirth as a doctrinaire petty bourgeois "republican of the heart". His concept of the importance and usefulness of the Reichsbanner was indeed promoted in an emotionally charged fashion. But was there more to that concept than parades and constitution day rhetoric? Even those who might agree with Wirth's diagnosis of the republic's ills and who sympathized with him personally became progressively disenchanted. His propagandizing, to some of them at least, seemed to be merely tilting with windmills. ${ }^{2}$ The problem, however, is of a somewhat different order. The starting point of all Wirth's political activities was his profound attachment to the republican state. The greatest service performed at Weimar, he insisted, was the preservation of a united German state when so many doubted this was possible. The new republican state having been secured from without then had to be secured from within, in both a social and a political sense - and that was the task of the Reichsbanner and similar organizations. ${ }^{3}$ Wirth may have been a doctrinaire republican but a doctrinaire leftist he was not, and his étatisme was often overlooked by critics and supporters. ${ }^{4}$

${ }^{1}$ Heinrich Teipel, Wir müssen aus dem Turm heraus! (Berlin, 1925); Teipel, "Die Krise des deutschen Reichstags", in: WAZ, No 6, Feb. 6 and No 7, Feb. 13,1926 . Wirth's supporters in the DDP evidently had similar ideas. Cf. the remarks of the trade unionist Anton Erkelenz: "Ich würde es für das Richtigste halten wenn die Gruppen die sich unter den Namen Republikanische Union ein gemeinsames Ziel gesetzt haben, sich zu einem einheitlichen Parteikörper verschmelzen würden." Meeting of DDP Vorstand, Nov. 6, 1926, in NSDAP-HA, $37 / 730$.

${ }^{2}$ Cf. Josef Emonds, "Proletariat und katholische Partei. Ein offenes Wort von Links", in: Abendland, III (Feb., 1928), pp. 134-37; Carl von Ossietzky, "Feuer im Osten", in: Die Weltbühne, XXIII (June 14, 1927), pp. 925-30; Walther Koch, "Können Sozialismus und Katholizismus zusammenarbeiten?", in: Sozialistische Monatshefte, XXXIV (April, 1928), pp. 279-80.

3 Wirth, "Der 11. August", in: Germania, No 334, Aug. 11, 1924. Cf. Wirth's letter to Hans Lammers, Aug. 10, 1933: "Ich verstehe es, wenn meine politischen Gegner mich wegen meiner innerpolitischen Haltung angreifen. Darüber sehe ich weg. Meine nationalpolitische Ehre aber geht allem vor. Darin unterscheide ich mich garnicht von anderen Zeitgenossen, die die nationale Ehre besonders stark betonen." Alte Reichskanzlei: Personalakten Josef Wirth (National Archives Microcopy T-120), serial 8443, reel 3352, frames E594177-80.

"See Germania, No 498, Nov. 14, 1924 (Wirth's comments on the "Bürgerblock"); Gotthard Jasper, Der Schutz der Republik. Studien zur staatlichen Sicherung der Demokratie in der Weimarer Republik (Tübingen, 1963), p. 242 (Wirth's remarks before the Reichstag Uberwachungsausschuss Sept. 15, 1921); Karl Griewank, "Dr. Wirth und die Krisen der Weimarer Republik", Wissenschaftliche Zeitschrift der Friedrich-Schiller-Universität Jena/Gesellschafts- und sprachwissenschaftliche Reihe, I (1951-52), pp. 1-10 (on Wirth's "kleinbürgerlicher Herzensrepublikanismus"). 
Wirth undoubtedly saw himself, and was seen by others, as an "apostle of republican state-conviction" 1 among the working class in the mid-twenties. When seen in perspective, however, Wirth's commitment to the Reichsbanner was problematical in several respects, and must be balanced against other considerations. Indications appeared from time to time that he was not above using the Reichsbanner to serve his own ends. ${ }^{2}$ Moreover, Wirth had never taken an active part in the executive organs of the Reichsbanner (such as the Bundesvorstand) even though Center membership in the upper echelons of the organization was a critical question. The former Chancellor's conduct with respect to the Reichsbanner matched his behavior in his own party. The support of other figures, such as the Berlin Center leaders Karl Spiecker, Rektor Franz Kellermann, and Karl Schreiner was always more consistently loyal than that of Wirth. In addition, the constant party bickering and lack of agreement on major issues within the Müller cabinet led Wirth to deplore increasingly that there were "scarcely two dozen republicans" who could sit down and discuss matters in common. In spite of the numerical strength of the Reichsbanner, a corresponding expression of political leadership in the parties of the republican left had not been found. Wirth tacitly concluded by 1929 that his platform for republican unity was a lost cause. By the following year he had abandoned - with a certain unintentional but ironic symbolism - the journal of his "Republican Union", the Deutsche Republik. ${ }^{3}$ Wirth insisted he had not cut ties with the left, nor did he intend to leave the Reichsbanner in the lurch. But to face political facts squarely, one had to adjust to new conditions. ${ }^{4}$ The adjustment became his rationale for entering the Brüning cabinet as Minister of the Interior, with the hope of some of his followers that he could serve effectively as a bridge to the SPD. In the absence of Wirth's support,

1 Rohe, p. 260.

2 In 1927, after repeated pleas from Reichsbanner leaders, Wirth finally made a speaking tour throughout Württemberg but only after local Reichsbanner leaders promised to promote the official organ of his "Republican Union", the Deutsche Republik, more than in the past. The issue was sensitive because the Reichsbanner enjoyed only limited success in attracting Center members in Württemberg. Wirth's conduct, however, was not at all out of keeping with his character. See the Lagebericht of the Württemberg state police, Oct. 19, 1927, p. 2 in NSDAP-HA, 58/1400.

"Wirth, "Vor zehn Jahren und heute", in: DR, III (Feb. 8, 1929), pp. 577-81; "Ende des Vertrauens?", ibid. (Feb. 15, 1929), pp. 609-14. Cf. Wirth to Wilhelm Groener, Dec. 2, 1930, in Wilhelm Groener Papers (National Archives Microcopy M-137), reel 25, Stück 230.

"Wirth, "Die Ereignisse und ihre Bedeutung", in: DR, IV (Dec. 14, 1929), pp. 321-23; Rheinische Zeitung, No 335, Dec. 6, 1929; undated letter [Dec., 1929] of Wirth to Wilhelm Sollmann, Sollmann Papers, Box 3. 
however, the loyalty of Centrists such as Kellermann and Schreiner to the Reichsbanner became more than ever the loyalty of a courageous and determined but politically ineffectual minority. ${ }^{1}$

Considering the position of the Center's Weimar partners, prospects for achieving republican unity were hardly promising. In part, this was the fault of the SPD although in part it was just as much the fault of the Democrats and Center. From the start, therefore, the question of the Reichsbanner's supra-party character posed formidable problems. The rank and file of the organization were overwhelmingly, and in some areas exclusively, socialist, while the leadership was largely in socialist hands. This situation complicated the Reichsbanner's official insistence down to the end that it was a republican Bund above the parties. Moreover, on the socialist and intellectual left were those who had no use for what they sarcastically called "fine and lofty Volksgemeinschaftsbrei" propagated by "prominent big guns [grosse Kanonen] such as Josef Wirth". ${ }^{2}$ The leaders of the SPD could not make the final break from class party to state party. ${ }^{3}$ The republic failed to generate a republican mystique among its officers, leaving its soldiers and NCO's to fend for themselves. ${ }^{4}$ Leaders of the DDP were, for the most part, blinded by class antagonism to socialists in the Reichsbanner. In any case, democratic liberalism was in no position to rally its pitifully shrinking electorate for militant republicanism.

For the Center, the political course of the Wirth group, which included a more active participation in the Reichsbanner, was unacceptable. Such a course might indeed have torn apart the party. Even a more stable and consistent personality than Wirth, such as Erzberger, would have been no more successful. The Center's leaders envisioned a basically conservative political order, one that would provide continuity with the party's pre-war aims. These same leaders might be willing to work informally, on an individual basis, or even in a party coalition with the SPD. But they were interested in no more

1 Rohe, p. 300; "Joseph Wirth auf der Reichsliste", in: Die Weltbühne, XXIV (April 24, 1928), pp. 623-24. It is more than likely that Wirth's stand was connected to promises he had made to party leaders in 1928 to carry on his "further political activity in concert with the leaders of the party and the Fraktion, in accordance with the principles of the Christian conception of the state." Report in Marx Papers 239; also Becker, "Wirth und die Krise des Zentrums", pp. 481-82.

" Klassenkampf, II (Jan., 1928), pp. 12-13. Cf. Alfons Steinger, “Republikanische Union”, in: Die Weltbühne, XXII (Sept. 21, 1926), pp. 446-48.

${ }^{3}$ Rohe, pp. 52, 314-42; Michael Stürmer, Koalition und Opposition in der Weimarer Republik 1924-1928 (Düsseldorf, 1967), p. 257.

"Karl Thieme, "Deutscher unter Deutschen", in: Hochland, LX (Oct.-Nov., 1968), pp. 622-23. 
than a superficial engagement with the Reichsbanner, and their goals could not really be reconciled with Wirth's kind of emotional-political commitment to the republican state. The commitment was in fact condemned by Wirth's own Baden Center as "republican integralism". ${ }^{1}$

Two related problems came together in the Center's relationship with the Reichsbanner. First, party leaders disliked associating the Center too closely with the Reichsbanner at the risk of shattering its fragile class balance. But for about the same reasons they also did not want to break all ties with the organization. Characteristically, the problem was solved by doing neither. The dilemma of the Center after 1918 was that it could speak for a bare majority of Catholic voters, but it could not speak for all of them. ${ }^{2}$ The party, quite simply, could neither wholeheartedly endorse the republic nor could it reject the republic. The result was creeping political paralysis, evident long before the vote on the Enabling Act in March, 1933 (when it was already too late).

The second problem, which can only briefly be alluded to here, was one inherited from the nineteenth century. The two sides of the problem were the relationship of German Catholicism to the national movement, and the political-psychological "trauma" which resulted from an often referred-to "Kulturkampf mentality". 3 There were certain fairly obvious parallels here to the situation of German socialism, and the Center (like the SPD) was never successful in solving the issue. Whether or not the situation could have been altered by a radical reordering of politics, by the Reichsbanner's republican élan, is open to question. German Catholics by and large were certainly unprepared for such an answer. The point is, the opportunity was never used.

The Reichsbanner was hardly a panacea. But it did represent one type of political style and one set of attitudes very important in the 1920 's. There can be little doubt that attempted extra-parliamentary solutions to the republic's political problems at least contributed to an atmosphere of latent crisis. With considerable justice, one might deplore this state of affairs. Even some Windthorstbund spokesmen

\section{Frankfurter Zeitung, No 405, June 2, 1927.}

2 Johannes Schauff, Die deutschen Katholiken und die Zentrumspartei (Köln, 1928); DR, II (Jan. 20, 1928), pp. 517-18. The same point was made by Catholics on the right and on the left who were not in the party, although they differed radically on aims and means. Cf. Martin Spahn to President Paul von Hindenburg, April 30, 1925, in AR: Zentrumspartei 1919-1926, L1833/5713/L530123-6; Heinrich Mertens to Wilhelm Sollmann, Nov. 7, 1926, Sollmann Papers Box 3. 3 Hans Maier, "Katholizismus, nationale Bewegung, und Demokratie in Deutschland", in: Hochland, LVII (April, 1965), pp. 318-33; Heinrich Lutz, Demokratie im $Z$ wielicht. Der Weg der deutschen Katholiken aus dem Kaiserreich in die Republik (Munich, 1963), pp. 91-123. 
were concerned about certain aspects of the Reichsbanner, and warned it would be dangerous for the Center to abandon its traditional teaching before any "Verbandsideologie". In case of a conflict, the Bïnde should be absorbed by the parties and not vice-versa. ${ }^{1}$ The Center's responsible leaders regarded the Reichsbanner as, at best, a necessary evil. Preferring to concentrate on "objective work" in the business of government, they operated in almost predictable and - it must be said - rather unimaginative catagories. ${ }^{2}$

Together with the republic it was sworn to uphold, the Reichsbanner failed, but during its existence it proved to be an excellent barometer for the shift of political forces. Likewise, the Center's role in the Reichsbanner corresponded to its political ambivalence and even opportunism after $1918,{ }^{3}$ and mirrored its relationship with the left in general and the Social Democrats in particular. The insistence of many Center leaders that the Reichsbanner was only a "socialist" organization became in the end a kind of self-fulfilling prophecy. The Center's leaders may indeed have prevented a large part of the Catholic voting masses from falling into social and political radicalism. But it was difficult to see for what they were preserved. The Center was prepared to throw itself into the breach in 1933, but not for the republic. Fearful of being left out of the "national awakening", the party resigned itself instead to a national catastrophe.

1 A. H. Berning, "Die ausserparlamentarischen Verbände", in: Das Junge Zentrum, IV (Mar., 1927), pp. 58-72.

2 Recent attempts to rehabilitate Center leaders such as Brüning and (to a lesser degree) Ludwig Kaas demonstrate at least that attitudes and positions taken from 1930 to 1933 were more responsible than critics have usually conceeded. But this simply enlarges the dimensions of the problem. See Ferdinand A. Hermens and Theodor Schieder (eds), Staat, Wirtschaft und Politik in der Weimarer Republik. Festschrift für Heinrich Brüning (Berlin, 1967); Konrad Repgen, Hitlers Machtergreifung und der deutsche Katholizismus. Versuch einer Bilanz (Saarbrücken, 1967).

'Morsey, Zentrumspartei, p. 609 refers to the Center's "Taktieren und Lavieren". 